\title{
Does Faith Concordance Matter? A Comparison of Clients' Perceptions in Same Versus Interfaith Spiritual Care Encounters with Chaplains in Hospitals
}

\author{
Anke I. Liefbroer ${ }^{1,2}$ (D) $\cdot{\text { Ineke } \text { Nagel }^{3}}^{2}$ \\ Accepted: 19 March 2021/ Published online: 11 June 2021 \\ (C) The Author(s) 2021
}

\begin{abstract}
In religiously pluralized societies, caregivers frequently care for patients or clients with a religious, spiritual, or secular orientation that differs from their own. Empirical studies exploring the implications of this faith diversity for spiritual care interactions between caregivers and clients are scarce. Some literature suggests that similarities in faith orientation between caregivers and clients relate to better professional caring relationships than encounters with dissimilar faith orientations, while other studies suggest that faith similarities do not relate, or relate only under certain conditions, to the way in which professional caring relationships are perceived. This study supports the second line of thought. Based on a survey among 209 clients and 45 chaplains in hospitals in the Netherlands, it shows that clients in faith-concordant encounters evaluate the spiritual care encounter just as positively as do clients in faith-discordant encounters. This is in line with broader trends of secularization and blurring of boundaries between the religious, spiritual, and secular domains.
\end{abstract}

Keywords Religion $\cdot$ Spiritual care $\cdot$ Diversity $\cdot$ Clients $\cdot$ Concordance

\section{Introduction}

Diversity is often framed - in scientific literature and in popular debates alike - as something that is challenging, especially when it comes to religious diversity (e.g., Becci \& Roy, 2015; Brown \& Brown, 2011; Fawcett \& Noble, 2004). As such, many argue that specific skills are

Anke I. Liefbroer

a.i.liefbroer@vu.nl

1 Faculty of Religion and Theology, Vrije Universiteit Amsterdam, De Boelelaan 1105, 1081 HV Amsterdam, The Netherlands

2 Tilburg School of Catholic Theology, University of Tilburg, Tilburg/Utrecht, The Netherlands

3 Faculty of Social Sciences, Vrije Universiteit Amsterdam, Amsterdam, The Netherlands 
needed to interact fruitfully in interfaith encounters, and initiatives have been undertaken to equip professionals in multifaith and multicultural settings to develop such skills (Anderson, 2004; Flohr, 2009; Ganzevoort et al., 2014; Hodge, 2018; Lartey, 2003). Apparently, when religion is discussed or performed outside of congregations and in interactions between people with different religious or secular worldviews, attention needs to be paid specifically to how such interactions take shape.

Meanwhile, scholars argue that religion is becoming increasingly pluralized in Western societies, leading to a blurring of boundaries between the religious, spiritual, and secular (Ammerman, 2013; Taylor, 2007; Woodhead, 2016). Whereas some adhere to one religious tradition without self-identifying as spiritual, others identify as spiritual and religious, or as spiritual but not religious, or as secularized, or as belonging to more than one religious tradition. This situation led us to question how to think of religion and religious differences in interactions where a person's religious, spiritual, or secular $(\mathrm{R} / \mathrm{S})$ orientation is relevant, such as in spiritual care interactions in hospitals - an "edge" where religion is visible in secular organizations outside of congregations (Bender et al., 2013; Cadge \& Konieczny, 2014). Understanding the dynamics of interfaith spiritual care encounters and the ways in which religious differences are negotiated may function as "analytic starting points" for reconsidering how to think theoretically about religion in secular contexts (Cadge \& Sigalow, 2013).

Our interest in these interactions is twofold. First, we are interested in whether (and, if so, under what conditions) religious differences relate to the way in which such interactions are perceived or evaluated, and, second, we aim to investigate whether religious differences relate to how these spiritual care interactions are shaped in secularized and pluralized contexts, i.e., regarding clients' experiences with, activities during, and the content of the encounter. Chaplains form our main focus in this regard. Being experts in spiritual care provision, they frequently meet people with all kinds of worldviews - religious, spiritual, and secular (Cadge, 2012) - and form an excellent case for studying the relationship between faith concordance and the ways in which spiritual care encounters are evaluated and take shape. Chaplains often formally affiliate with a religious or humanistic tradition, thereby representing that specific tradition, while at the same time working in and being employed by a secular organization (De Groot, 2018; Ganzevoort et al., 2014; Swift, 2013). By their presence, they thus function on behalf of both the traditional and the secular, which raises questions about their professional identity as being religiously authorized (Swift, 2013). In interfaith encounters where a shared $\mathrm{R} / \mathrm{S}$ understanding is lacking, how do these chaplains negotiate religious differences between themselves and their clients (Cadge \& Sigalow, 2013), and how is this perceived by their clients?

Empirical research investigating clients' perspectives on same-faith and interfaith encounters in spiritual care is scarce; in a systematic review of the literature, five studies were identified that focus on this perspective (Liefbroer et al., 2017). These studies offer different suggestions regarding the role of faith concordance in perceptions of spiritual care encounters: while some suggest that same-faith encounters relate to more positive perceptions of spiritual care than interfaith encounters (Ellis \& Campbell, 2005; Hodge \& Lietz, 2014), others suggest quite the opposite (Mayers et al., 2007; Pesut \& Reimer-Kirkham, 2010) (we will explore this in more detail below). These studies all used qualitative methods to explore clients' perspectives; to our knowledge, no empirical study has been conducted to test hypotheses on the relationship between faith concordance and evaluations and shapes of spiritual care encounters. 
In this study, the role of religious diversity (same-faith versus interfaith encounters) is investigated in chaplain-client interactions via a quantitative survey among 209 clients and their caregivers $(n=45)$ in hospitals in a multifaith European country - the Netherlands. As in other Western countries, the population of the Netherlands is highly secularized and pluralized in terms of religion, with many not (or no longer) adhering to a religious tradition (53\%) and others belonging to a variety of Christian denominations (22\% Roman Catholic, $15 \%$ various Protestant denominations), Islam (5\%), or other religious traditions (5\%) (CBS, 2018) and/or combining elements from various traditions (17-23\%) (Berghuijs, 2017). This diversity is reflected in chaplains' authorizations. While some are registered as unaffiliated chaplains, others are ordained by or formally affiliated with a Protestant, Catholic, Muslim, Jewish, Buddhist, Hindu, or humanistic organization (Ganzevoort et al., 2014; Zock 2019). Since in Dutch hospitals chaplains often work in a 'territorial mode,' caring for all clients on a certain unit, they are likely to meet clients adhering to a variety of religious traditions as well as to no tradition (Liefbroer \& Berghuijs, 2019).

First, we focus on religious diversity in relation to the way in which spiritual care encounters are evaluated and explore the conditions under which this may play a role (e.g., whether faith concordance is only relevant for certain clients or for certain chaplains). Second, we investigate religious diversity in relation to how spiritual care encounters take shape, specifically regarding clients' experiences with, activities during, and the content of spiritual care encounters.

\section{Background}

\section{Same-faith and interfaith spiritual care encounters}

In line with diversity being framed as a challenge (Becci \& Roy, 2015; Brown \& Brown, 2011; Fawcett \& Noble, 2004), social psychological theory suggests that people are more likely and better able to connect with someone who is similar to and in the same group as them. According to the similarity-attraction hypothesis, the more people are similar to each other, the more they like each other (Byrne, 1971), and, following social identity theory (Tajfel \& Turner, 1986), people in the same ingroup are likely to view themselves more positively than those in other groups. Support for these theories and evidence that this applies to religious diversity is found in research among Dutch citizens: respondents felt more attracted to those who were perceived as similar to themselves - in terms of nationality, employment status, and religion - than to those who were dissimilar to themselves (Van Oudenhoven et al., 2000). Other studies suggest that (dis)similarity affects not only liking but also the quality of the perceived relationship. For instance, Liu et al. (2010) show that the quality of communication in negotiation is perceived lower in intercultural than in same-culture negotiation, and, when it comes to same-faith and interfaith relations, same-faith couples report higher marital quality than interfaith couples (Myers, 2006) while interfaith couples report more marital conflict (Chinitz \& Brown, 2001; Petts \& Knoester, 2007). In the literature on caregiver-patient interaction, Ellis and Campbell (2005) interviewed 10 patients and reported that concordant belief systems facilitated patient-physician spiritual interaction while discordant belief systems might create barriers. Hodge and Lietz (2014), based on focus groups with 20 patients and 20 therapists, note how differences in $\mathrm{R} / \mathrm{S}$ beliefs between patients and therapists can lead therapists to impose their beliefs on clients and offend clients because of conflicting belief 
systems. In a survey among Dutch spiritual caregivers, respondents report a higher estimated satisfaction with their spiritual care provision for clients in same-faith than in interfaith encounters (Liefbroer \& Berghuijs, 2019).

Meanwhile, other theory suggests that faith similarity is not that important in how relationships are perceived and that, even if similarity plays a role at first sight, its role may diminish with more interactions. The contact hypothesis (Allport, 1954) supposes that differences between people diminish when they get to know each other in person. In line with this, some empirical studies suggest that faith concordance does not play a role in evaluations of spiritual care encounters. For instance, Mayers et al. (2007) interviewed 10 religious clients and note that having the same R/S affiliation as the therapist was not important during therapy, and Pesut and Reimer-Kirkham (2010) report that many patients feel that other, general characteristics - such as kindness, respect, and humor - matter more for the quality of the professional caring relationship than $\mathrm{R} / \mathrm{S}$ characteristics. Also, in a survey among university counseling center therapists, the perceived similarity between therapists' and clients' $\mathrm{R} / \mathrm{S}$ values was not associated with the strength of the therapeutic relationship (Kellems et al., 2010).

These two lines of reasoning lead to contrasting ideas: on the one hand, the idea that faith concordance does not relate to the way in which spiritual care encounters are perceived and, on the other hand, the idea that faith concordance does relate to this and does so in a positive manner (i.e., when caregiver and client have the same faith, they perceive the encounter more positively than when they do not share the same faith).

Same faith can be conceived in several ways. The first and most direct way is to consider affiliation with the same faith tradition as a form of same faith; we refer to this as faith concordance (e.g., a Protestant chaplain with a Protestant client form a faith-concordant encounter, and a humanistic chaplain with a Muslim client form a faith-discordant encounter). Straightforward as this measurement may seem, it fails to consider the fact that chaplains often present themselves in general terms, without necessarily explicating their affiliation with a specific tradition (Cadge, 2012). Clients therefore may not always know the affiliation of the chaplain and/or may have a different perception of faith concordance than there actually is. Also, assessing a person's faith in a unidimensional way (i.e., affiliation) ignores other aspects of a person's R/S orientation, and many have argued for multidimensional or more nuanced ways of conceptualizing a person's faith (e.g., Glock \& Stark, 1965; Smart, 1998). One of the ways to assess someone's faith in a way that is not fixed to religious traditions as such is by using Wulff's (1997) model of approaches to religion. Wulff (1997) differentiates between approaches to religion that include or exclude transcendence (vertical axis) and approaches to religion that consider religion in a literal or symbolic way (horizontal axis), combining these approaches in a matrix that leads to four different approaches. Following these approaches, a third way of assessing same-faith and interfaith encounters is to consider having the same approach to religion (rather than affiliating with a religious tradition as such) as the same faith. Based on these lines of thought, to investigate how religious diversity relates to the ways in which spiritual care encounters are evaluated, we tested three hypotheses:

H1 Clients in faith-concordant spiritual care encounters report more positive evaluations of these encounters than clients in faith-discordant spiritual care encounters.

$\mathrm{H} 2$ The more clients assume they have the same faith as the chaplain, the more positively they evaluate spiritual care encounters. 
H3 Clients holding the same approach to religion as the chaplain report more positive evaluations of spiritual care encounters than clients holding a different approach to religion.

\section{Conditions: Intrinsic religiosity, exclusivism, and the chaplain's professional profile}

Not all clients and chaplains respond to religious diversity in the same way (Cadge \& Sigalow, 2013), and there may be (at least) three factors moderating this relationship. First, clients' R/S motivation may moderate the relation between faith concordance and evaluations of spiritual care encounters, and a distinction is commonly made between extrinsic and intrinsic religious motives (Allport \& Ross, 1967). Whereas extrinsic religiosity refers to instrumental or utilitarian motives for a person to be(come) religious (e.g., for security, sociability, or status), intrinsic religiosity refers to an intrinsically motivated form of religiosity in which other needs are of less significance. The more intrinsically motivated a person is, the more important it may be to discuss R/S themes with someone with whom this faith can be shared.

Second, Merino (2010) reports that theological exclusivism - the view that one's own religious worldview is the only right one - is associated with negative attitudes toward religious diversity and toward including those of other faiths into one's community. This suggests that those holding an exclusive view toward religiosity may be more positive about faith-concordant spiritual care encounters (or more negative about faith-discordant spiritual care encounters) than others.

Third, the chaplains' professional profile may moderate the relationship between faith concordance and the evaluated encounter, and in this regard two positions regarding religious diversity in spiritual care are distinguished (Liefbroer et al., 2017; Liefbroer et al., 2019). Some emphasize the particularities of chaplains' own $\mathrm{R} / \mathrm{S}$ orientation in providing spiritual carethey are referred to as 'particularists' - and others focus on generic aspects of spiritual care provision and the importance of spiritual care provision to all - the 'universalists.' A study among Dutch chaplains suggests that chaplains' professional profiles correlate with their (perceived) ability to provide interfaith spiritual care in that higher scores on particularism relate to lower scores on ability and higher scores on universalism relate to higher scores on ability (Berghuijs \& Liefbroer, 2017). Accordingly, we hypothesized that:

H4 The higher the intrinsic religiosity of clients' faith, the stronger the relation between faith concordance and clients' evaluations of spiritual care encounters.

H5 The higher the exclusivity of clients' faith, the stronger the relation between faith concordance and clients' evaluations of spiritual care encounters.

H6 The more chaplains hold a universalist perspective on and feel able to provide interfaith spiritual care, the weaker the relationship between faith concordance and clients' evaluations of spiritual care encounters.

\section{Experiences with, activities during, and the content of spiritual care encounters}

In addition to focusing on religious diversity in relation to evaluations of spiritual care encounters, the second aim of this paper is to investigate how religious diversity relates to the shape of spiritual care encounters. In his study of the universal dimensions and functions of religions, Saroglou (2011) differentiates between belonging (identity), bonding (emotions), behaving (morality), and believing (cognitions). In this proposed model, these dimensions and 
functions are universal aspects of religion across cultural contexts, and we assume that these dimensions play a role in spiritual care encounters as well. Therefore, we investigate faith concordance (belonging/affiliation) in relation to the shape of spiritual care encounters according to clients' experiences with them (bonding/emotional aspect), the activities during these encounters (behavioral aspect), and their content (believing/cognitive aspect).

The chaplain's professional identity is often described in terms of three roles: the professional, personal, and confessional roles (Bidwell \& Marshall, 2006; Ganzevoort \& Visser, 2007; Heitink, 2001; Liefbroer et al., 2019), or the chaplain as counselor, companion, and spiritual guide. In faith-discordant encounters, this third role - the chaplain as a spiritual guide - may be the most difficult to perform due to $\mathrm{R} / \mathrm{S}$ differences, and clients may thus be more likely to experience the chaplain in this role in faith-concordant than in faith-discordant encounters. Furthermore, the activities during and content of spiritual care encounters may differ between faith-concordant and -discordant spiritual care encounters. In their diary-study of 1440 chaplaincy visits, Idler et al. (2015) identified various chaplains' activities - broadly categorized under "doing" or spiritual communication (e.g., prayer, performing a ritual) and "being" or general communication (e.g., active listening) - and topics of the conversation - broadly categorized under "practical matters" (e.g., work, finance) and "ultimate concerns" (e.g., emotional well-being, existential matters). While activities using general communication, such as listening, may be very common in all such encounters, activities using spiritual communication may be more likely when both affiliate with the same faith (e.g., chaplains are more likely to pray with patients of the same faith (Galek et al., 2010)). Also, whereas clients may feel at ease discussing practical matters with all caregivers, they may be more likely to discuss ultimate concerns only with those affiliating with the same faith. We therefore tested the following hypotheses:

H7 Clients in faith-concordant spiritual care encounters more often experience the chaplain as a spiritual guide than clients in faith-discordant spiritual care encounters.

H8 Clients in faith-concordant spiritual care encounters report more spiritual communication activities than clients in faith-discordant spiritual care encounters.

H9 Clients in faith-concordant spiritual care encounters discuss ultimate concerns more than clients in faith-discordant spiritual care encounters.

\section{Data and methods}

\section{Design}

We used a quantitative, multilevel design, surveying chaplains in hospitals in the Netherlands and, for each of them, some of their clients. The survey for chaplains included questions about their personal characteristics and their R/S orientation. Directly after having a conversation with a chaplain, clients of these chaplains were asked to participate in a survey as well, consisting of questions about the encounter and questions about the clients' personal characteristics and their R/S orientation (see Measures).

\section{Procedure}

Spiritual care departments were approached by the first author via email and telephone. If spiritual care departments were unwilling to participate, the first author 
inquired about their reasons for being unwilling (see Sampling strategy, response, and sample). If spiritual care departments agreed to participate, the researcher asked (and was given) permission to conduct the research in agreement with the head of the spiritual care department and (if needed) the ethics review committee of that hospital.

The first author was present during approximately one week in each participating hospital, and during that week chaplains asked their clients directly after a conversation took place if they would allow the researcher to visit the client for a survey about chaplaincy. If the client agreed, the researcher asked the client to participate in the research and to complete a survey on paper (see Measures; the researcher assisted the client with the survey when needed or preferred). During that same week, the researcher asked participating chaplains to fill out a survey and to maintain a list of the clients they met with (a) chaplains' reasons to not ask clients to participate in the survey and (b) clients' reasons for nonresponse.

\section{Sampling strategy, response, and sample}

Data gathering took place between December 10, 2018, and April 18, 2019. Spiritual care departments of both academic and nonacademic hospitals in the Netherlands were approached if they met the following inclusion criteria: (a) their hospital was in one of the most urban areas of the Netherlands (in the provinces North-Holland, SouthHolland, Utrecht, or Flevoland), where the diversity of $\mathrm{R} / \mathrm{S}$ worldviews is thought to be higher than in more rural areas, and (b) the spiritual care department consisted of a team with at least three chaplains. Spiritual care departments were encouraged to participate with the entire team, but participation with several members but not all of the team was possible as well. All spiritual care departments that met the inclusion criteria $(n=19)$ were approached for the study, and chaplains from 11 spiritual care departments agreed to participate. Most of the nonparticipating departments (seven out of eight) mentioned "being too busy" or "not having enough time" as their main reason for not participating in the study. Other reasons mentioned for not taking part in the study included hesitation or difficulty approaching and finding clients to participate (3 out of 8 ) and reluctance to use quantitative measures to investigate spiritual care interactions (1 out of 8 ).

A total of 45 chaplains participated in the study. About half were male $(44 \%)$ and half were female $(56 \%)$, and their mean age was 50.40 years $(\mathrm{SD}=12.00)$, ranging from 23 to 65 . All were highly educated (7\% in applied sciences, 93\% at university level). The mean years of experience was 13.57 years $(\mathrm{SD}=8.82)$, ranging from 0 to 34. Most chaplains were authorized or ordained by a Protestant (31\%), Catholic $(20 \%)$, Islamic $(10 \%)$ or humanistic organization $(18 \%)$ or were recognized by the RING-GV, a Dutch organization that examines the competence of chaplains who are not authorized or ordained by a religious or humanistic organization (7\%). Some respondents $(16 \%)$ were not authorized.

Clients were approached for the study if they had received spiritual care by a chaplain in the hospital setting. These clients often were inpatients, but others to whom spiritual care was provided could participate as well, such as outpatients and informal or professional caregivers. Exclusion criteria were (a) age below 18; (b) cognitive impairment, such as suffering from severe dementia or delirium; (c) staying in an intensive care unit; or (d) an acute crisis in which taking part in a survey was 
not appropriate. For an overview of response and nonresponse, see Appendix Fig. 1. ${ }^{1}$

A total of 209 clients participated in the study. Half of them were male (49\%) and half were female $(51 \%)$, and $1 \%$ were "other/don't want to say." The mean age was 64.79 years $(\mathrm{SD}=$ 17.02), ranging from 18 to 95 . Most (44\%) had a low educational level, some (18\%) had a middle education level, and around one third (35\%) had a high educational level. ${ }^{2}$ Compared to the Dutch population (32\%, 38\%, and 30\%, respectively; CBS, 2019), those with a middle educational level were somewhat underrepresented. Most conversations lasted 10-20 min (26\%), 20-30 $\mathrm{min}(29 \%)$, or 30-60 $\mathrm{min}(30 \%)$. Few conversations lasted less than $10 \mathrm{~min}$ $(8 \%)$ or longer than $60 \mathrm{~min}(8 \%)$.

\section{Measures: Dependent variables}

Clients' evaluations of the encounter ( $\mathrm{Cl}$ ) were measured using two items. ${ }^{3}$ Client satisfaction - a construct commonly used in healthcare evaluation studies (see, e.g., Marin et al., 2015; Shen et al., 2018)—was measured by asking clients, "How satisfied are you with the chaplaincy encounter?" and clients' perceived benefit from the conversation was measured by asking them, "To what extent did you benefit from the conversation with the chaplain?"

Clients' experiences with the encounter $(\mathrm{Cl})$ were assessed following the roles of the chaplain as counselor, companion, and spiritual guide (Bidwell \& Marshall, 2006; Ganzevoort \& Visser, 2007; Heitink, 2001; Liefbroer et al., 2019). Four to seven items were developed for each role to capture the extent to which clients experienced the chaplain in each of these roles. Items that related to the chaplain as counselor were inspired by the roles described for psychological conversations (e.g., "I have gained insight into my situation"; Lang \& Van der Molen, 2012); items that reflected the chaplain as companion were derived from research that focused on the role of expert-volunteer caregivers (e.g., "I feel I was being listened to"; Post \& Liefbroer, 2019); and items reflecting the chaplain as spiritual guide were derived from research among church members and their experiences in conversations with pastors (e.g., "I am reconciled"; Bruinsma-de Beer, 2006).

Activities during the encounter $(\mathrm{Cl})$ were divided into five activities that focus on spiritual communication (e.g., practicing rituals, prayer) and three activities that focus on general communication (e.g., listening, asking questions), inspired by activities identified by Idler et al. (2015). Clients were asked to indicate whether each of these activities took place during the encounter and for how long.

\footnotetext{
${ }^{1}$ A possible limitation of this design may be a selection bias due to selection by spiritual caregivers based on the evaluation of the encounter (i.e., leading to an underrepresentation of respondents who did not give a favorable evaluation of the encounter). However, Appendix 2 shows that main reasons for nonresponse of clients were other factors, such as cognitive impairment, inappropriate situations (e.g., due to illness or sensitivity of the topic), language barriers, or practical reasons (e.g., patient going home), suggesting that a selection bias is not plausible.

${ }^{2}$ Specifically, respondents' educational level was categorized as follows: none: $4 \%$; primary school: $9 \%$; lowerlevel vocational education: $18 \%$; lower-level + vocational education: $14 \%$; middle-level vocational education: 14\%; high school: $4 \%$; BA/MA applied sciences: $24 \%$; university level: $11 \%$.

${ }^{3}$ Some variables were only included in the survey for clients (referred to as $\mathrm{Cl}$ ), some only in the survey for chaplains (referred to as $\mathrm{Ch}$ ), and some in both surveys (referred to as $\mathrm{ClCh}$ ). Because no validated and standardized measurements are available for many of the variables, several measures were developed for the purpose of this study and, as much as possible, were based on or inspired by previous research. The psychometric characteristics of the measures are described in the Results section.
} 
Based on Idler et al. (2015), for content of the encounter (Cl) a differentiation was made between discussing practical matters (e.g., work, finances) and ultimate concerns (e.g., emotions, existential themes). Clients were asked to indicate for 11 of these topics whether and, if so, how much time they had spent discussing these topics with the chaplain.

\section{Measures: Independent variables}

Faith concordance (ClCh) was operationalized according to affiliation with an $\mathrm{R} / \mathrm{S}$ tradition, and both clients and chaplains were asked to indicate which tradition they affiliated with, choosing from Protestantism, Catholicism, Judaism, Islam, Buddhism, Hinduism, humanism, other (please specify), or none. If respondents affiliated with more than one tradition, they were asked to choose the most important one. If both client and chaplain affiliated with the same R/S tradition, the interaction was classified as faith concordant. If the two affiliated with a different $\mathrm{R} / \mathrm{S}$ tradition, or if either one or both did not affiliate with an $\mathrm{R} / \mathrm{S}$ tradition, the interaction was classified as faith discordant.

The perceived faith concordance $(\mathrm{Cl})$ was measured by asking, "To what extent do you think your religious or spiritual orientation is the same as that of the chaplain?"

The similarity in approach to religion (ClCh) was operationalized based on Wulff's (1997) model of approaches to religion, and a distinction was made between inclusion and exclusion of transcendence and between a literal or symbolic worldview interpretation, leading to four possible positions. For inclusion versus exclusion of transcendence, three items were selected based on the Dutch SOCON survey (e.g., "There is a supreme being who controls life"; Eisinga et al., 2005). For a literal versus symbolic worldview, three items were formulated inspired by the Post-Critical Belief Scale (e.g., "Religious and spiritual texts are meant to be followed literally"; Duriez et al., 2005; Fontaine et al., 2003). ${ }^{4}$

\section{Measures: Moderating variables}

Intrinsic religiosity $(\mathrm{Cl})$ was assessed using the three-item intrinsic religiosity (IR) scale of the Duke University Religion Index (DUREL; Koenig \& Büssing, 2010, translated by Ouwehand et al., 2020). ${ }^{5}$

The measurement of the exclusivism of clients' faith $(\mathrm{Cl})$ was inspired by a questionnaire measuring religious tolerance (Broer et al., 2014) and the inclusivism and exclusivism subscales as well as by the World Value Survey (Inglehart et al., 2014). ${ }^{6}$ Six items were developed, consisting of three items that focused on inclusivism (e.g., "I like to connect with people who have a different religious or worldview orientation than my own") and three items that focused on exclusivism (e.g., "I am convinced that my religious or worldview orientation is the only right one").

\footnotetext{
${ }^{4}$ The Post-Critical Belief Scale was considered too long (33 items; 18 items in the short form) and too Christianity-focused for our multifaith sample. We therefore adapted several items of this scale into a shorter formulation that is inclusive for non-Christian respondents.

5 As a check for other forms of respondents' religiosity, the other subscales of the DUREL-organized religious activity (ORA) and personal (or nonorganized) religious activity (NORA) - were included in the survey as well. ${ }^{6}$ The items included in these surveys were reformulated to make the items suitable for our sample (e.g., by formulating shorter sentences than the ones used in the religious tolerance measurement; Broer et al., 2014).
} 
The chaplain's professional profile with regard to $R / S$ diversity (Ch) was based on a survey conducted by Liefbroer and Berghuijs (2019). ${ }^{7}$ Twelve items were included, of which four focused on particularism, four on universalism, and four on the chaplain's ability to provide interfaith spiritual care.

\section{Measures: Control variables}

Similarity in gender (ClCh), age (ClCh), and educational level $(\mathrm{Cl})$ were included as control variables. The similarity between chaplains' and clients' gender was recoded into a dichotomous variable (different vs same gender), the similarity in age was recoded into a continuous variable based on difference scores between the age of clients and chaplains, and only the clients' educational level was used (all chaplains are highly educated). In addition, clients' gender $(\mathrm{Cl})$, age $(\mathrm{Cl})$, and religious affiliation $(\mathrm{Cl})$ were included as control variables.

In Dutch healthcare settings, although many chaplains work in a territorial manner (providing care to all clients within a particular unit), some work in a categorical manner (primarily providing care to those affiliated with the same tradition as themselves) (Liefbroer \& Berghuijs, 2019). Some clients may feel that faith concordance is important and therefore may have asked for a chaplain with the same background. To control for the bias this may create (e.g., those who initiate a faith-concordant encounter may be more likely than others to evaluate such conversations positively), we included a question regarding who initiated the encounter $(\mathrm{Cl})$.

\section{Analysis}

We analyzed the data using SPSS. Factor analyses with oblimin rotation were used to investigate the homogeneity of the constructs. The data set was hierarchically organized, with several observations of clients for each chaplain. Linear mixed models were used to test the hypotheses, including the clustering within chaplains as a random effect and control variables (sex, age, educational level, religious affiliation, and similarity in sex and age) in all analyses. In cases with positive effects of faith affiliation on the dependent variable, a robustness check was performed on responses by those clients who did not ask for a chaplain with a specific faith affiliation to make sure that such effects were not due to this selection.

\section{Results}

Below, we first describe the descriptive results of our study for each of the variables. A summary of the descriptive statistics is presented in Table 1. Second, we describe the results of our study for the multivariate analyses that correspond to the hypotheses.

\section{Descriptive results: Dependent variables (C)}

Overall, respondents were positive about their encounters with chaplains. Specifically, clients rated their satisfaction with the encounter as an $8.22(\mathrm{SD}=1.23)$ on a 1 (=very dissatisfied $)$ to

\footnotetext{
${ }^{7}$ Some of the items were adjusted based on the findings by Liefbroer and Berghuijs (2019) (e.g., "I think it can be helpful to have a conversation with a spiritual caregiver who does not explicitly belong to the same religious or worldview orientation" was deleted from their factor analysis because of a communality of $<.20$, and was adjusted by us to "I think that for conversations it makes no difference whether the chaplain and the client belong to the same or a different religious or worldview orientation").
} 
Table 1 Overview of descriptive statistics for dependent, independent, moderating, and control variables

\begin{tabular}{|c|c|c|c|c|}
\hline & Variables ${ }^{1}$ and hypotheses $(\mathrm{H})$ & Range & $\mathrm{M}$ or $\%$ & SD \\
\hline \multirow[t]{7}{*}{ Dependent variables } & Evaluation of the encounter $(\mathrm{H} 1-\mathrm{H} 6)$ & $1-10$ & 7.80 & 1.45 \\
\hline & $\begin{array}{l}\text { Experiences with the encounter }(\mathrm{H} 7) \text { : } \\
\text { Spiritual guide }\end{array}$ & $1-5$ & 2.19 & 1.28 \\
\hline & Counselor & $1-5$ & 2.47 & 1.14 \\
\hline & Companion & $1-5$ & 4.07 & .80 \\
\hline & Activities during the encounter $(\mathrm{H} 8)$ & $1-5$ & 1.21 & .55 \\
\hline & Spiritual communication ${ }^{2}$ & & & \\
\hline & General communication ${ }^{2}$ & $1-5$ & 4.65 & .63 \\
\hline \multicolumn{5}{|c|}{ Content of the encounter (H9) } \\
\hline & Ultimate concerns & $1-5$ & 2.66 & .85 \\
\hline & Practical matters & $1-5$ & 1.98 & .75 \\
\hline \multirow[t]{3}{*}{ Independent variables } & Faith concordance (H1, H4-H6) & 0,1 & $24 \%$ & \\
\hline & Perceived faith concordance $(\mathrm{H} 2)^{3}$ & $1-10$ & 6.65 & 2.81 \\
\hline & Match in approach to religion $(\mathrm{H} 3)$ & 0,1 & $40 \%$ & \\
\hline \multirow[t]{7}{*}{ Moderating variables } & Intrinsic religiosity $(\mathrm{H} 4)^{3}$ & $1-5$ & 3.38 & 1.52 \\
\hline & Exclusivism of client's worldview (H5) & $1-5$ & 2.06 & 1.23 \\
\hline & Exclusivism $^{3}$ & & & \\
\hline & Inclusivism $^{3}$ & $1-5$ & 3.71 & 1.12 \\
\hline & The chaplain's professional profile (H6) & $1-5$ & 4.31 & .66 \\
\hline & Perspective on interfaith spiritual care ${ }^{3}$ & & & \\
\hline & Ability to provide interfaith spiritual care ${ }^{3}$ & $1-5$ & 3.95 & .65 \\
\hline \multirow[t]{3}{*}{ Control variables ${ }^{4}$} & Same gender & 0,1 & $53 \%$ & \\
\hline & Age similarity ${ }^{3}$ & $-55-0$ & -20.31 & 14.13 \\
\hline & Educational level ${ }^{3}$ & $1-8$ & 4.94 & 2.11 \\
\hline
\end{tabular}

${ }^{1} \mathrm{~N}$ for each variable ranges from 179 to 207 , except for the chaplain's professional profile $(n=45)$

${ }^{2}$ In the multivariate analyses, ranked scores are used for this variable (because of the relatively large skewed distribution of these items)

${ }^{3}$ In the multivariate analyses, centered scores are used for this variable

${ }^{4}$ Clients' gender, age (see Sampling strategy, response, and sample) and religious affiliation (see Table 2) are also used as control variables

10 (= very satisfied $)$ scale and how much they benefitted from the encounter as a $7.36(\mathrm{SD}=$ 1.94) on a 1 (= not at all) to 10 (= very much) scale. Since these items are highly correlated $(\mathrm{r}=.66 ; p<.01)$, the average of the scores on both questions was taken as a measure of the evaluation of the encounter (Cronbach's alpha $=.75$ ).

The results of the factor analysis for experiences with, activities during, and content of the encounter are described in Appendixes Tables 7, 8, and 9. Based on a factor analysis of 19 items concerning experiences with the encounter, three scales were constructed that fit the data and the theoretical roles of the chaplain as companion, spiritual guide, and counselor. The chaplain as companion was most prominent in the way in which respondents experienced the chaplain, followed by the chaplain as counselor. The chaplain as spiritual guide was experienced the least by respondents.

Factor analysis of eight items focusing on activities during the encounter led to a two-factor solution in line with our theoretical concepts consisting of activities that focused on spiritual communication and activities that focused on general communication. Overall, activities that focused on spiritual communication were relatively rare compared to activities that focused on general communication.

The factor analysis of nine items concerning the content of the encounter yielded two factors relating to the theoretical concepts of practical matters and ultimate concerns. Overall, ultimate concerns were discussed more often in the encounters than practical matters. 


\section{Descriptive results: Independent variables (C/S/CS)}

For the first measure of interfaith versus same-faith encounters, see Table 2. Around one fourth of conversations were faith-concordant conversations (24\%)-implying that both chaplain and client affiliated with the same R/S tradition - and around three fourths of conversations were faithdiscordant (77\%). Most of the faith-concordant encounters were between Protestants (7\%), Catholics (10\%), or Muslims (6\%). In the analyses (see below), we also checked for faith concordances that included Catholic-Protestant combinations (46\% faith concordance; $54 \%$ faith discordance).

For the second measure, most clients had the perception that their faith was more similar to than different from the chaplain's faith $(\mathrm{M}=6.65 ; \mathrm{SD}=2.81$, on a range from 1 (= completely different) to 10 (= completely the same)). The perceived faith concordance correlated positively with the actual faith concordance, but only moderately so $(\mathrm{r}=.30, p<.01)$.

For the third measure of interfaith versus same-faith encounters, the factor analysis of six items focusing on respondents' approach to religion led to a two-factor solution (see Appendixes Tables 10 and 11). The first scale concerns the inclusion versus exclusion of transcendence, and the second scale concerns respondents' literal versus symbolic interpretation of religion. On average, both clients and chaplains assumed inclusion rather than exclusion of transcendence and interpreted religion in a symbolic rather than literal way. The similarity in approach to religion between clients and chaplains was calculated using the scores on each axis (exclusion-inclusion and literal-symbolic $)^{8}$ to divide respondents into the four quadrants. Forty percent of the encounters consisted of spiritual care interactions in which both the client and the chaplain had the same approach to religion; in most of these encounters, both included transcendence and had a symbolic interpretation of religion (Q2; see Table 3).

\section{Descriptive results: Moderating variables}

Descriptive results for intrinsic religiosity, inclusivism and exclusivism, and chaplains' professional profile are presented in Appendixes Tables 12, 13, and 14. For intrinsic religiosity, clients' R/S orientation was of moderate importance to them.

The factor analysis of six items concerning the inclusivism and exclusivism of clients' R/S orientation yielded one factor for each. Overall, respondents scored higher on inclusivism than on exclusivism.

The factor analysis of 12 items concerning the chaplain's professional profile led to two factors in line with our theoretical concepts: one concerning a universalist perspective on interfaith spiritual care - in which a lower score indicated a more particularist and a higher score indicated a more universalist perspective - and another concerning the chaplain's ability to provide interfaith spiritual care. Overall, respondents were very willing to provide spiritual care to clients with a variety of $\mathrm{R} / \mathrm{S}$ orientations and felt quite able to do so.

\section{Results of hypotheses testing}

Interfaith spiritual care encounters $(\mathrm{H} 1, \mathrm{H} 2$, and $\mathrm{H} 3)$ Results of the tests of $\mathrm{H} 1, \mathrm{H} 2$, and $\mathrm{H} 3$ are presented in Table 4. First, we hypothesized that clients in faith-concordant spiritual care encounters would report more positive evaluations of spiritual care encounters than clients in

\footnotetext{
${ }^{8}$ Cutoff scores were below 3 or above 3 (scale ranged from 1 to 5). If the mean score on the subscale was exactly 3 , respondents were randomly selected (using SPSS randomization) into one side of the axis.
} 


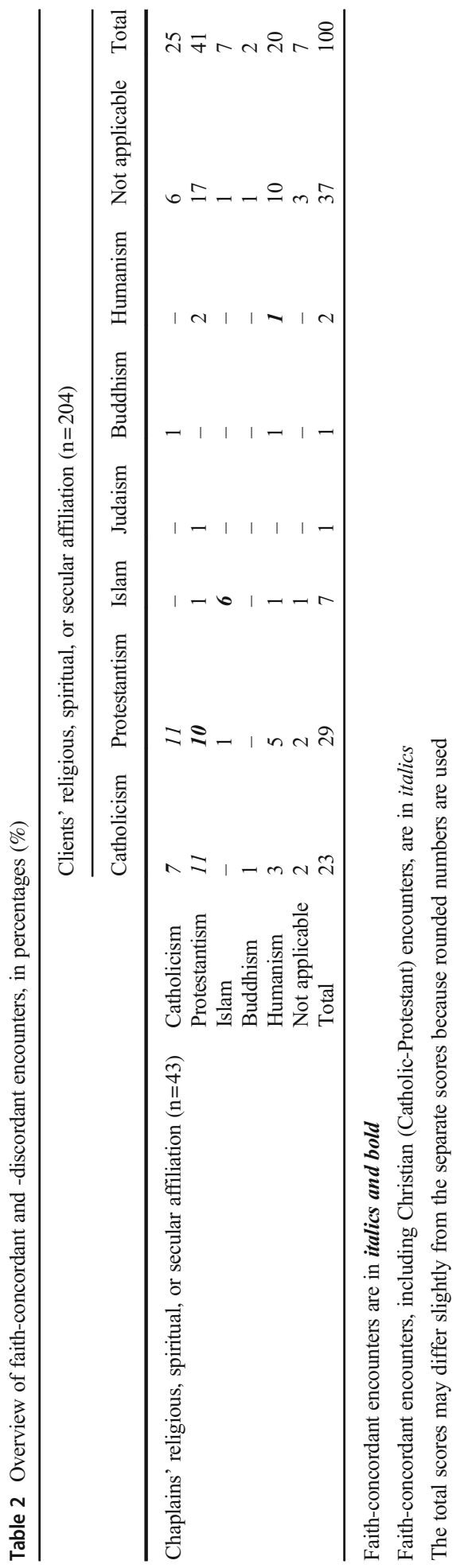


Table 3 Overview of matches in approach to religion, in percentages (\%)

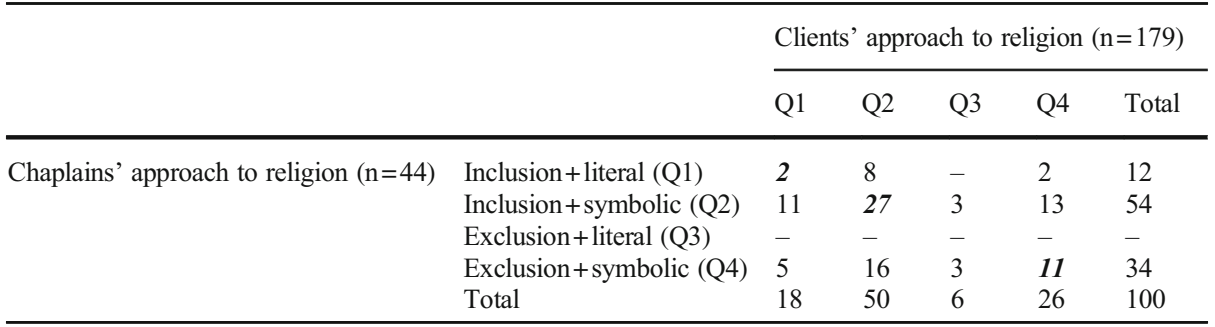

Matches in approach to religion are in italics and bold

faith-discordant encounters. Table 4 shows that no significant differences were found between faith-concordant and -discordant encounters regarding clients' evaluations of spiritual care encounters, thereby rejecting $\mathrm{H} 1 .^{9}$ By contrast, the more respondents had the perception that there is faith concordance, the more positively they evaluated the spiritual care encounter, thus supporting H2. Third, no significant differences were found between having or not having the same approach to religion in terms of the evaluation of the spiritual care encounter, which rejects H3. Effect sizes (betas) for these hypotheses are .05, .36, and .07, respectively.

In addition, the findings presented in Table 4 indicate that educational level was related to the way in which the spiritual care encounters were evaluated; the higher the client's educational level, the higher the evaluation of the spiritual care interaction (betas are $.20, .14$, and .20 , respectively).

Intrinsic religiosity (H4), exclusivism (H5), and the chaplain's professional profile (H6) Results of the tests of $\mathrm{H} 4, \mathrm{H} 5$, and $\mathrm{H} 6$ are presented in Table 5. First, it was hypothesized that the higher the intrinsic religiosity of clients' faith, the stronger the relation between faith concordance and clients' evaluations of their spiritual care encounter would be. However, no significant differences in this interaction were found.

Second, the extent to which clients thought of their faith in an exclusive manner did not moderate the relation between faith concordance and clients' evaluations of the spiritual care encounter. The interaction effects of inclusivism and of exclusivism with faith concordance on clients' evaluations were not significant. ${ }^{10}$

Third, it was hypothesized that the more chaplains held a universalist perspective and perceived themselves as being able to provide interfaith spiritual care, the weaker the relationship between faith concordance and clients' evaluations of spiritual care encounters would be. However, neither of these hypothesized interaction effects related to chaplains' professional profile were significant.

Thus, hypotheses H4, H5, and H6 are all rejected by the findings of this study (the betas are $-.24,-.00,-.18,-.11$, and .18 , respectively).

Results of the tests of H7, H8, H9 are presented in Table 6 First, this table reports that there is insufficient evidence that clients who encountered a chaplain with a concordant faith experienced them more in the role as spiritual guide than did clients in faith-discordant encounters, thus rejecting H7. No significant differences were found between faith-

\footnotetext{
${ }^{9}$ This hypothesis was also checked using Christian combinations (Protestant-Catholic) as faith-concordant rather than -discordant encounters. This did not change these findings.

${ }^{10}$ This may in part be due to the low reliability of the scale for inclusivism (Cronbach's alpha $=.52$; see Appendix Table 13).
} 
Table 4 Evaluation of the encounter; overview of multivariate results for $\mathrm{H} 1, \mathrm{H} 2$, and $\mathrm{H} 3$

\begin{tabular}{|c|c|c|c|c|c|c|c|c|c|}
\hline & & $\mathrm{B}^{1}$ & $\mathrm{SE}^{1}$ & & B & SE & & B & SE \\
\hline & Constant & 7.87 & .51 & & 8.13 & .48 & & 8.44 & .50 \\
\hline \multirow[t]{2}{*}{$\begin{array}{l}\text { Same-faith } \\
\text { versus } \\
\text { interfaith }\end{array}$} & $\begin{array}{l}\text { Faith concordance } \\
\qquad(\mathrm{H} 1)\end{array}$ & .17 & .27 & $\begin{array}{l}\text { Perceived faith } \\
\text { concordance } \\
(\mathrm{H} 2)\end{array}$ & $.19 * *$ & .04 & $\begin{array}{l}\text { Same approach } \\
\text { to religion }(\mathrm{H} 3)\end{array}$ & .21 & .20 \\
\hline & Faith discordance & - & - & & & & $\begin{array}{l}\text { Different approach } \\
\text { to religion }\end{array}$ & - & - \\
\hline \multirow[t]{2}{*}{ Gender } & Same gender & .05 & .20 & & .09 & .20 & & .23 & .19 \\
\hline & Different gender & - & - & & - & - & & - & - \\
\hline Age & Age similarity ${ }^{1}$ & .00 & .01 & & .00 & .01 & & -.00 & .01 \\
\hline $\begin{array}{l}\text { Educational } \\
\text { level }\end{array}$ & $\begin{array}{l}\text { Clients' } \\
\text { educational } \\
\text { level }\end{array}$ & $.14 *$ & .05 & & $.10 *$ & .05 & & $.14 * *$ & .05 \\
\hline$N$ & & 197 & & & 186 & & & 177 & \\
\hline
\end{tabular}

*Significant at $\mathrm{p}<.05 ; * *$ significant at $\mathrm{p}<.01$

All linear mixed models presented here are controlled for clients' religious affiliation, gender, and age

${ }^{1} \mathrm{~B}=$ Regression coefficient, $\mathrm{SE}=$ standard error

${ }^{2} \mathrm{~A}$ higher score indicates greater age similarity (or less age difference)

concordant and -discordant encounters with regard to experiencing the spiritual caregiver as counselor and/or companion (the betas are $.08, .01$, and -.02 , respectively).

Second, Table 6 indicates that H8 is rejected by our findings because the respondents in faith-concordant encounters did not report significantly more spiritual communication activities than did the respondents in the discordant condition. ${ }^{11}$ Similarly, for activities relating to general communication, no significant differences were found between faith-concordant and discordant encounters (the betas are -.05 and -.00 , respectively).

Finally, contrary to $\mathrm{H} 9$, ultimate concerns and practical matters were not discussed more often in faith-concordant than -discordant conditions (the betas are -.16 and - .14, respectively). ${ }^{12}$

\section{Discussion and conclusion}

This study investigated whether (and, if so, under what conditions) religious differences relate to the way in which spiritual care interactions are evaluated and shaped in secularized and pluralized contexts. The analyses of responses by clients in hospitals after receiving spiritual care by a chaplain show that, overall, affiliating with the same religious tradition and having the same approach to religion (Wulff, 1997) does not significantly relate to clients' evaluations of spiritual care encounters (H1, H3) - nor when considering moderating effects such as clients' intrinsic religiosity, the inclusivism or exclusivism of their religion or worldview orientation, or chaplains' professional

\footnotetext{
${ }^{11}$ This may in part be due to the rare occurrence of these activities.

${ }^{12}$ By contrast, these concerns are discussed significantly more often in faith-discordant than -concordant encounters.
} 


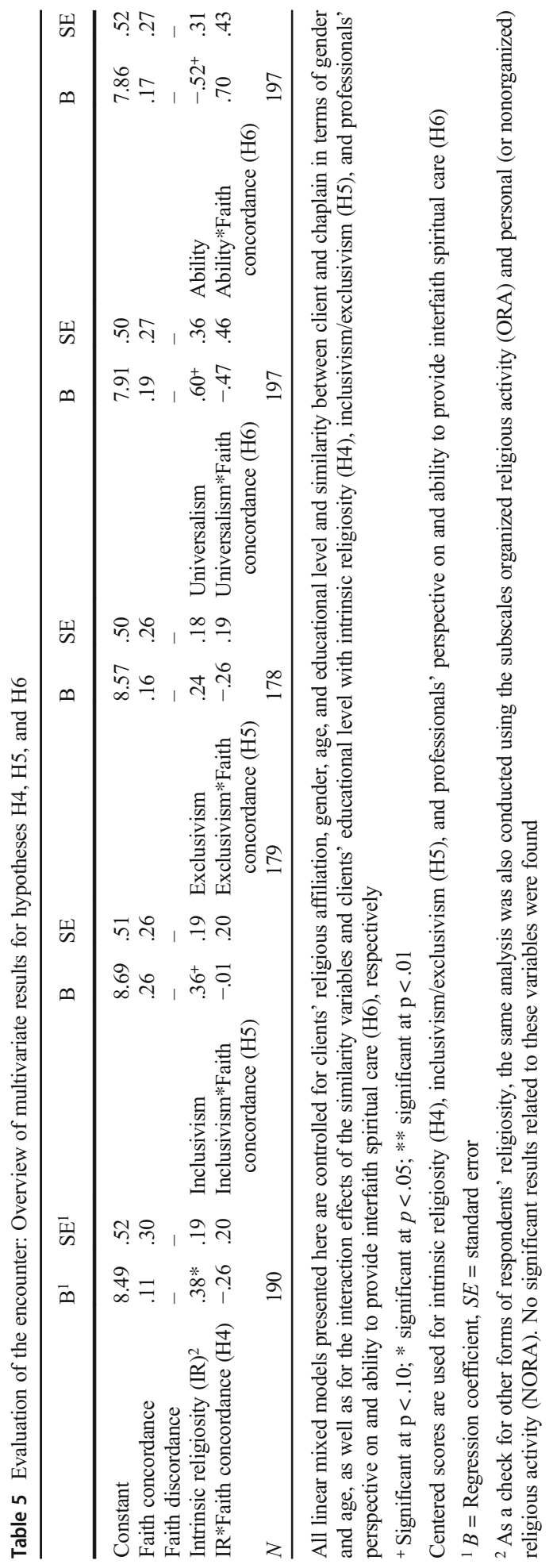




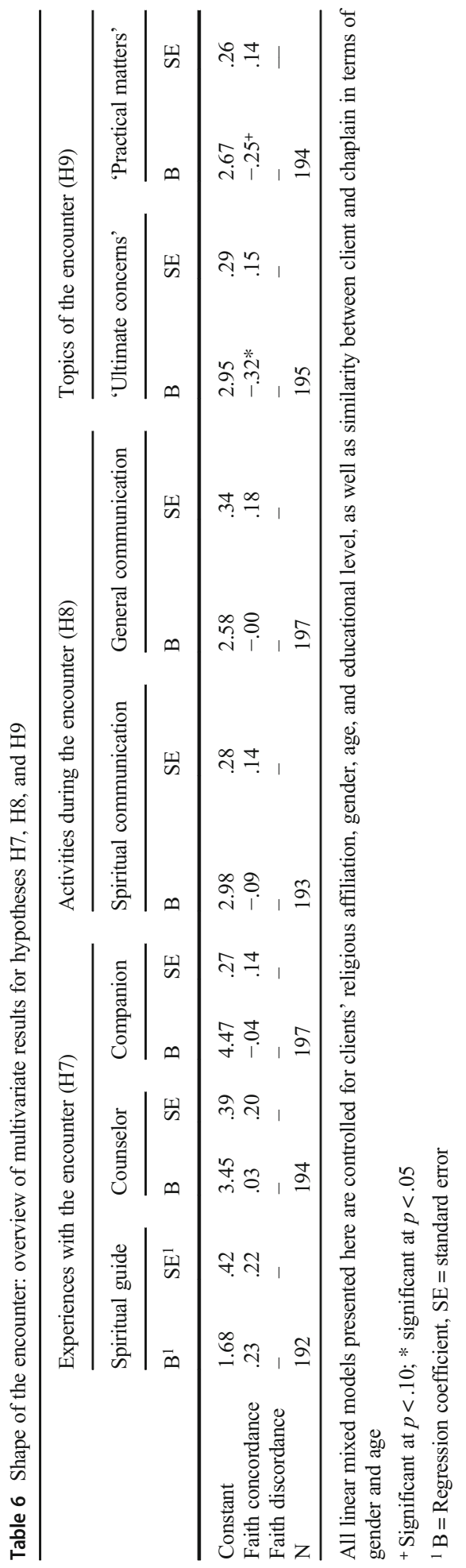


profile $(\mathrm{H} 4, \mathrm{H} 5, \mathrm{H} 6)$. Furthermore, whether clients affiliate with the same or a different faith as the chaplain does not significantly matter for the way in which they experience the chaplain (i.e., as spiritual guide, counselor, or companion), nor do the activities that take place during the conversation (e.g., listening, speaking, praying, performing rituals) (H7, H8). Also, clients in same-faith encounters do not discuss ultimate concerns more than those in faith-discordant encounters (H9).

There are several explanations for these findings, and they may complement one another. First, the findings could be supported by the notion that religious differences diminish when people get to know each other (e.g., following the contact hypothesis; Allport, 1954). However, it is uncertain what getting to know each other implies in spiritual care encounters that are sometimes single events and that occur in a relationship where there is a clear role difference between the chaplain and the client. Second, our findings may be explained in relation to participating chaplains' expertise: on average, chaplains were very positive about their ability to provide interfaith spiritual care, and their (self-reported) ability may explain why faith-concordant encounters were not evaluated more positively than faith-discordant encounters. A third, more sociological, way to account for these findings is by considering the context in which these encounters take place. In a secularized and pluralized context such as the Netherlands, for many people religious traditions may not (or may no longer) play a central role in addressing existential themes. Rather, people draw from a variety of sources, including religious and nonreligious or secular ones (e.g., Berghuijs, 2017; Liefbroer et al., 2018). In line with this trend, many chaplains in secularized societies seem to be inclined to use broad spiritual language when providing spiritual care (Cadge \& Sigalow, 2013; Christensen et al., 2019; Idler et al., 2015), thereby transforming the chaplaincy profession from a "religious service" to a more "existential care" model (Stifoss-Hanssen et al., 2019 p60.) In such a context, for most people religious differences may not (or may no longer) be of much importance when discussing existential themes and evaluating spiritual care encounters.

This study is one of the first to investigate clients' perspectives on religious diversity in spiritual caregiving in a quantitative way. Yet, it is limited in several ways. First, with its sample size of 209 spiritual care encounters, this study only identified large and moderate effect sizes for the independent variables regarding religion (betas of approximately .3 and above). There could be smaller differences with regard to religious differences in spiritual care encounters (with effect sizes below .3) that we may not have been able to identify. However, if by conducting this study with larger sample sizes we would possibly identify such smaller differences (and not large or moderate differences), it is questionable whether such findings would be of any clinical significance for clients when encountering chaplains in practice.

Second, most respondents to the survey affiliated with Catholicism, Protestantism, humanism (chaplains), or no tradition (clients), and only a small percentage affiliated with other traditions (Islam, Buddhism, Judaism). The investigation of same-faith versus interfaith encounters thus mainly seems to be a comparison between caregivers and patients who both affiliate with a Christian tradition compared to those who do not affiliate with a Christian tradition. Therefore, we are unsure to what extent the findings apply to adherents of other religions, such as Islam, Judaism, Hinduism, or Buddhism. Findings by Abu-Ras and Laird (2011) suggest that spiritual care provision for Islamic patients may require specific knowledge of Islam (e.g., regarding ritual performances or discussing issues of life and death), and Ganzevoort et al. (2014) suggest that providing Muslim, Hindu, or Buddhist spiritual care may require specific roles and competencies of the chaplain. Empirical research among clients affiliating with these religious traditions is needed to investigate in more depth how spiritual care is perceived by these clients.

Third, since the empirical data for this study were collected in the Netherlands among clients after they were visited by a chaplain, questions arise concerning the applicability of this study's findings for 
other contexts and other professions. To the extent that other countries, such as other European countries or the United States and Canada, are pluralizing and secularizing, the findings are relevant for those contexts as well. However, in contexts where the society is less pluralized, or where pluralization of the organizational structure (e.g., chaplains working in a territorial mode for all clients regardless of their faiths) is less common, clients may respond differently to interfaith encounters. Furthermore, by choosing client-chaplain interactions as our main focus, this study included encounters in which spiritual or existential themes were specifically aimed at and in which professionals were trained to address these themes. In encounters with other professional caregivers - e.g., those for whom addressing spiritual or existential themes is less central to their practice - faith concordance may have a different role (e.g., Van Nieuw Amerongen-Meeuse et al., 2018). Future research is needed to examine the extent to which the findings of this study are applicable to the practice of (spiritual) caregiving in other contexts and by other healthcare professionals.

Regarding the practice of spiritual care, our findings suggest that, within the religiously pluralized context of the Netherlands, for most clients spiritual care encounters do not have to be same faith in order for them to give a positive evaluation of the spiritual care encounter. Other aspects of the spiritual care encounter seem to be more important for their perception and evaluation of the encounter, such as whether they feel as if their faith corresponds to the chaplain's faith (H2; although this could have also been the result of a positive evaluation), which may be a form of experiencing a 'personal connection.' Indeed, in a survey among chaplains in the Netherlands, most chaplains reported that other aspects were more important for the establishment of a spiritual care encounter than their religious orientation, such as their availability, whether they had met before, and whether there was a personal connection (Liefbroer \& Berghuijs, 2017).

Also, our study shows that the client's educational level often plays a role in how spiritual care encounters are evaluated. One of the questions related to this is whether the more positive evaluations of these encounters is caused by the similarity between chaplains' and clients' educational levels (e.g., similarity-attraction hypothesis; Byrne, 1971), and/or by the client's educational level (e.g., the more highly educated clients are, the more they appreciate addressing spiritual or existential themes), and/or by the high educational levels of chaplains (e.g., they may be more likely to focus on cognitive rather than other forms of spiritual caregiving, as exemplified by the finding that, overall, spiritual communication activities are performed much less than general communication activities in spiritual caregiving; see also Idler et al., 2015). Further research, including (quasi-)experimental rather than correlational designs, is needed to unravel the relation between these and other factors in clients' evaluations of spiritual care encounters.

The main findings of this study - that differences with regard to religious affiliation do not significantly relate to clients' evaluations of spiritual care encounters in hospital settings - should encourage scholars to rethink the role of religion in addressing spiritual and existential themes outside of congregations. The findings among these chaplains, who are experts in addressing existential themes, suggest that referring to religious affiliation as such is not (or is no longer) of central relevance in these contexts and that future research is needed to identify how existential and spiritual themes are addressed and what factors are important for effectively discussing and communicating such topics in secularized and religiously pluralized contexts. 


\section{Appendix 1}

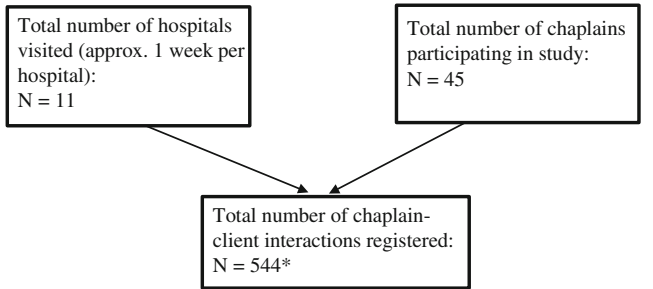

$\mathrm{N}=544^{*}$

Number of clients not asked by chaplain to meet with the researcher: $\mathrm{n}=259$

$\mathrm{n}=2$ age below 18 years

$\mathrm{n}=20$ cognitive impairment (e.g., dementia, delirium)

$\mathrm{n}=16$ in an intensive care unit

$\mathrm{n}=18$ in a crisis situation

$\mathrm{n}=74$ not appropriate or possible, due to situation of

patient (e.g., too ill, tired, confused) or to topic (e.g., too sensitive)

$\mathrm{n}=8$ psychiatric problem

$\mathrm{n}=20$ communication or language barrier

$\mathrm{n}=17$ interaction too short or first encounter

$\mathrm{n}=9$ did not want spiritual care

$\mathrm{n}=22$ practical reason (e.g., going home)

$\mathrm{n}=23$ approached before

$\mathrm{n}=7$ forgot or no time to ask

$\mathrm{n}=9$ combination of reasons

$\mathrm{n}=8$ other reason

$\mathrm{n}=5$ reason unknown

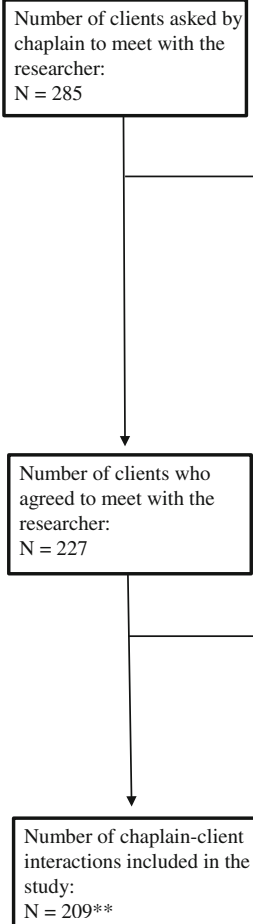

* Number of unique clients: $\mathrm{N}=499$; number of clients that were met several times during data gathering: $\mathrm{N}=45$.

** Number of unique clients: $\mathrm{N}=206$; number of clients meeting two chaplains: $\mathrm{N}=3$

Fig. 1 Flowchart of clients' response and non-response

Number of clients not included in the study: $\mathrm{n}=18$ $\mathrm{n}=4$ too ill or tired

$\mathrm{n}=5$ practical reason (e.g., visitors, went home)

$\mathrm{n}=2$ language barrier

$\mathrm{n}=4$ other reasons

$\mathrm{n}=3$ combination of reasons

in the

study:

$\mathrm{N}=209^{*}$

Number of clients who did not agree to meet with the

$\mathrm{n}=4$ combination of reasons

$\mathrm{n}=9$ reason unknown 


\section{Appendix 2}

Table 7 Experiences during the encounter: factor loadings $(>.35)$ for principal axis factoring with oblimin rotation $(n=159)$

\begin{tabular}{|c|c|c|c|c|c|c|}
\hline Variable & $\begin{array}{l}\text { Item } \\
\text { Because of the conversation with } \\
\text { the chaplain, ... }\end{array}$ & $\mathrm{M}^{2}$ & SD & $\begin{array}{l}\text { Factor } \\
\text { loading } \\
\text { factor } 1\end{array}$ & $\begin{array}{l}\text { Factor } \\
\text { loading } \\
\text { factor } 2\end{array}$ & $\begin{array}{l}\text { Factor } \\
\text { loading } \\
\text { factor } 3\end{array}$ \\
\hline \multirow{2}{*}{$\begin{array}{l}\text { Chaplain as } \\
\text { companion }\end{array}$} & I feel respected & 4.20 & .93 & .87 & - & - \\
\hline & I feel I was being listened to & 4.20 & .96 & .78 & - & - \\
\hline \multirow[t]{4}{*}{$\alpha=.83$} & I feel accepted & 4.04 & .96 & .73 & - & - \\
\hline & I feel understood & 4.08 & .97 & .69 & - & - \\
\hline & I was able to tell my story & 3.90 & 1.05 & .41 & - & - \\
\hline & Subscale total & 4.07 & .80 & & & \\
\hline \multirow{4}{*}{$\begin{array}{l}\text { Chaplain as } \\
\text { spiritual } \\
\text { guide } \\
\alpha=.82\end{array}$} & $\begin{array}{l}\text { I feel connected with my religious } \\
\text { or worldview tradition }\end{array}$ & 2.17 & 1.46 & - & .93 & - \\
\hline & $\begin{array}{l}\text { I feel connected to God or a } \\
\text { higher power }\end{array}$ & 2.21 & 1.52 & - & .85 & - \\
\hline & I am reconciled & 2.18 & 1.40 & - & .47 & - \\
\hline & Subscale total & 2.19 & 1.28 & & & \\
\hline $\begin{array}{l}\text { Chaplain as } \\
\text { counselor }\end{array}$ & $\begin{array}{l}\text { I have gained insight into my } \\
\text { situation }\end{array}$ & 2.32 & 1.36 & - & - & -.78 \\
\hline \multirow[t]{4}{*}{$\alpha=.82$} & $\begin{array}{l}\text { I am able to look at the situation } \\
\text { from a distance }\end{array}$ & 2.24 & 1.34 & - & - & -.76 \\
\hline & $\begin{array}{l}\text { I have started to think things } \\
\text { through }\end{array}$ & 2.32 & 1.40 & - & - & -.64 \\
\hline & I have been helped & 3.07 & 1.44 & - & - & -.53 \\
\hline & Subscale total & 2.47 & 1.14 & & & \\
\hline $\begin{array}{l}\text { Variance } \\
\quad \text { explained (\%) }\end{array}$ & & & & 39.92 & 15.90 & 10.91 \\
\hline
\end{tabular}

Note. Correlations between factors: $.24(1-2),-.50(1-3),-.39(2-3)$.

${ }^{1}$ The following items were deleted from analysis:

Due to loading on a different subscale then theoretically intended: "I am inspired."

Due to loading on two subscales simultaneously: "I feel at peace about my situation," "I feel connected with all living things," and "I feel supported."

Due to insufficient loading on the intended subscale (<.35): "I feel misunderstood."

Due to insufficient loading or not theoretically belonging to any of the subscales: "I am disappointed" and "I feel insecure."

${ }^{2}$ Ranging from 1 (= completely not) to 5 (= very much) 
Table 8 Activities during the encounter: factor loadings (>.35) for principal axis factoring with oblimin rotation $(n=199)$

\begin{tabular}{|c|c|c|c|c|c|}
\hline Variable $^{1}$ & $\begin{array}{l}\text { Item } \\
\text { During the encounter } \\
\text { with the chaplain, } \ldots{ }^{2}\end{array}$ & $\mathrm{M}^{3}$ & SD & $\begin{array}{l}\text { Factor } \\
\text { loading factor } 1\end{array}$ & $\begin{array}{l}\text { Factor } \\
\text { loading factor } 2\end{array}$ \\
\hline \multirow{4}{*}{$\begin{array}{l}\text { Spiritual communication } \\
\alpha=.73\end{array}$} & the chaplain prayed with or for me & 1.29 & .82 & .79 & - \\
\hline & $\begin{array}{l}\text { the chaplain read a philosophical, } \\
\text { religious or spiritual text }\end{array}$ & 1.23 & 63 & .69 & - \\
\hline & the chaplain performed a ritual & 1.13 & .57 & 62 & - \\
\hline & Subscale total & 1.21 & .55 & & \\
\hline \multirow{3}{*}{$\begin{array}{l}\text { General communication } \\
\alpha=.67\end{array}$} & the chaplain listened to me & 4.75 & .60 & - & .75 \\
\hline & the chaplain spoke with me & 4.54 & .89 & - & .68 \\
\hline & Subscale total & 4.65 & .63 & & \\
\hline Variance explained (\%) & & & & 41.43 & 28.44 \\
\hline
\end{tabular}

Note. Correlation between factors: -.18

${ }^{1}$ The alpha scores and factor analysis are based on ranked variables that were used because of the relatively large skewed distribution of these items

${ }^{2}$ The following items were deleted from analysis due to insufficient loading on the intended subscale $(<.35)$ : "the chaplain meditated with me," "the chaplain gave me advice," and "the chaplain asked me questions."

${ }^{3}$ Ranging from 1 (= not at all) to 5 (= all of the time)

Table 9 Content of the encounter: factor loadings ( $>.35)$ for principal axis factoring with oblimin rotation $(n=$ 176)

\begin{tabular}{|c|c|c|c|c|c|}
\hline Variable & $\begin{array}{l}\text { Item } \\
\text { During the encounter with the spiritual caregiver, we } \\
\text { discussed ... }\end{array}$ & $\mathrm{M}^{1}$ & SD & $\begin{array}{l}\text { Factor } \\
\text { loading } \\
\text { factor } 1\end{array}$ & $\begin{array}{l}\text { Factor } \\
\text { loading } \\
\text { factor } 2\end{array}$ \\
\hline \multirow{3}{*}{$\begin{array}{l}\text { Content } \\
\text { concerning } \\
\text { ultimate } \\
\text { concerns }\end{array}$} & $\begin{array}{l}\text { issues that touch upon things that matter most to me } \\
\text { in my life }\end{array}$ & 3.05 & 1.30 & .86 & - \\
\hline & issues that are of ultimate concern for me & 3.10 & 1.33 & .82 & - \\
\hline & how I emotionally or mentally feel & 3.03 & 1.30 & .59 & - \\
\hline \multirow[t]{5}{*}{$\alpha=.80$} & life questions or questions of meaning-making & 2.22 & 1.22 & .55 & - \\
\hline & family business or friendships & 2.57 & 1.19 & .47 & - \\
\hline & (parts of) my life story & 2.54 & 1.21 & .46 & - \\
\hline & $\begin{array}{l}\text { issues that relate to my worldview, religion or } \\
\text { spirituality }{ }^{2}\end{array}$ & 2.07 & 1.19 & .28 & - \\
\hline & Subscale total & 2.66 & .85 & & \\
\hline \multirow{5}{*}{$\begin{array}{l}\text { Content } \\
\text { concerning } \\
\text { practical } \\
\text { matters } \\
\alpha=.57\end{array}$} & $\begin{array}{l}\text { practical matters regarding the care I or my relative } \\
\text { are receiving (diagnosis, prognosis, treatment, } \\
\text { future scenarios, etc.) }\end{array}$ & 2.02 & 1.17 & - & .72 \\
\hline & $\begin{array}{l}\text { ethical questions concerning the care I or my relative } \\
\text { is receiving }\end{array}$ & 1.65 & 1.05 & - & .56 \\
\hline & practical matters (e.g., work, finances) & 1.60 & .97 & - & .44 \\
\hline & how I physically feel ${ }^{2}$ & 2.56 & 1.12 & - & .23 \\
\hline & Subscale total & 1.98 & .75 & & \\
\hline $\begin{array}{l}\text { Variance } \\
\quad \text { explained (\%) }\end{array}$ & & & & 34.05 & 12.10 \\
\hline
\end{tabular}

Note. Correlations between factors: .51

${ }^{1}$ Ranging from 1 (= not at all) to 5 (= all of the time)

${ }^{2}$ Although the factor loading for this item is relatively low, the item remained in the subscale because it theoretically was intended for this subscale and because it did not affect the reliability of the scale (excluding the item would lead to a maximum of .01 increase in $\alpha$ score) nor loaded on both subscales 
Table 10 Approach to religion (clients): factor loadings (>.35) for principal axis factoring with oblimin rotation $(n=159)$

\begin{tabular}{|c|c|c|c|c|c|}
\hline Variable & Item $^{1}$ & $\mathrm{M}^{2}$ & SD & $\begin{array}{l}\text { Factor } \\
\text { loading } \\
\text { factor } 1\end{array}$ & $\begin{array}{l}\text { Factor } \\
\text { loading } \\
\text { factor } 2\end{array}$ \\
\hline \multirow{4}{*}{$\begin{array}{l}\text { Inclusion of } \\
\text { transcendence } \\
\alpha=.69\end{array}$} & In my opinion, there is no God $^{3}$ & 2.12 & 1.59 & .93 & - \\
\hline & Human life is a coincidence ${ }^{3}$ & 2.51 & 1.65 & .41 & - \\
\hline & There is a supreme being who controls life & 3.44 & 1.66 & -.63 & - \\
\hline & Subscale total & 3.63 & 1.31 & & \\
\hline $\begin{array}{l}\text { Symbolic interpretation } \\
\text { of religion }\end{array}$ & $\begin{array}{l}\text { Religious and spiritual texts are meant to be } \\
\text { followed literally }{ }^{3}\end{array}$ & 2.06 & 1.61 & - & .98 \\
\hline \multirow[t]{2}{*}{$\alpha=.66$} & $\begin{array}{l}\text { Statements in religious and spiritual texts } \\
\text { should not be taken literally }\end{array}$ & 3.82 & 1.58 & - & -.49 \\
\hline & Subscale total & 3.84 & 1.41 & & \\
\hline Variance explained (\%) & & & & 43.94 & 24.79 \\
\hline
\end{tabular}

Note. Correlation between factors: -.27

${ }^{1}$ The following item was deleted from analysis due to insufficient loading on the intended subscale $(<.35)$ : "How one thinks about God or a higher power depends on the time and the place where one lives."

${ }^{2}$ Ranging from 1 to 5 ( 1 = totally disagree; $5=$ totally agree)

${ }^{3}$ Reversed in subscale score

Table 11 Approach to religion (chaplains): factor loadings (> .35) for principal axis factoring with oblimin rotation $(n=43)$

\begin{tabular}{|c|c|c|c|c|c|}
\hline Variable & Item $^{1}$ & $\mathrm{M}^{2}$ & SD & $\begin{array}{l}\text { Factor } \\
\text { loading } \\
\text { factor } 1\end{array}$ & $\begin{array}{l}\text { Factor } \\
\text { loading } \\
\text { factor } 2\end{array}$ \\
\hline \multirow{4}{*}{$\begin{array}{l}\text { Inclusion of } \\
\text { transcendence } \\
\alpha=.85\end{array}$} & In my opinion, there is no God ${ }^{3}$ & 2.07 & 1.15 & .99 & - \\
\hline & Human life is a coincidence ${ }^{3}$ & 2.32 & 1.20 & .53 & - \\
\hline & There is a supreme being who controls life & 3.25 & 1.37 & \multirow[t]{2}{*}{-.90} & \multirow[t]{2}{*}{-} \\
\hline & Subscale total & 3.62 & 1.09 & & \\
\hline $\begin{array}{l}\text { Symbolic interpretation } \\
\text { of religion }\end{array}$ & $\begin{array}{l}\text { Religious and spiritual texts are meant to be } \\
\text { followed literally }{ }^{3}\end{array}$ & 1.51 & .86 & - & $1.01^{4}$ \\
\hline \multirow[t]{2}{*}{$\alpha=.75$} & $\begin{array}{l}\text { Statements in religious and spiritual texts } \\
\text { should not be taken literally }\end{array}$ & 4.18 & 1.02 & - & -.59 \\
\hline & Subscale total & 4.34 & .84 & & \\
\hline Variance explained (\%) & & & & 54.56 & 24.97 \\
\hline
\end{tabular}

Note. Correlation between factors: -.37

${ }^{1}$ The following item was deleted from analysis due to correspondence with items included in the subscale among clients (see Appendix 2D): "How one thinks about God or a higher power depends on the time and the place where one lives."

${ }^{2}$ Ranging from 1 to 5 ( 1 = totally disagree; $5=$ totally agree)

${ }^{3}$ Reversed in subscale score

${ }^{4}$ This number $(>1.0)$ is probably the result of the small sample size in this factor analysis $(n=43)$ 
Table 12 Intrinsic religiosity: factor loadings $(>.35)$ for principal axis factoring with oblimin rotation $(n=187)$

\begin{tabular}{llccc}
\hline Variable & Item & $\mathrm{M}^{1}$ & SD & $\begin{array}{l}\text { Factor } \\
\text { loading } \\
\text { factor } 1\end{array}$ \\
\hline $\begin{array}{l}\text { Intrinsic religiosity } \\
\alpha=.83\end{array}$ & $\begin{array}{l}\text { My religious or worldview orientation is what really } \\
\text { lies behind my whole approach to life } \\
\text { I try hard to carry my religious or worldview orientation } \\
\text { into all my dealings in life } \\
\text { In my life, I experience the presence } \\
\text { of the Divine (i.e., God) }\end{array}$ & 3.27 & 1.80 & .93 \\
& $\begin{array}{l}\text { Scale total } \\
\text { Variance explained (\%) }\end{array}$ & 3.23 & 1.76 & .69 \\
\hline
\end{tabular}

${ }^{1}$ Ranging from 1 to 5 ( 1 = totally disagree; 5 = totally agree $)$

Table 13 Inclusivism and exclusivism of clients' religious, spiritual, or secular orientation: factor loadings (> $.35)$ for principal axis factoring with oblimin rotation $(n=155)$

\begin{tabular}{|c|c|c|c|c|c|}
\hline Variable & Item & $\mathrm{M}^{1}$ & SD & $\begin{array}{l}\text { Factor } \\
\text { loading } \\
\text { factor } 1\end{array}$ & $\begin{array}{l}\text { Factor } \\
\text { loading } \\
\text { factor } 2\end{array}$ \\
\hline \multirow[t]{4}{*}{$\begin{array}{l}\text { Exclusivism } \\
\alpha=.69\end{array}$} & $\begin{array}{l}\text { I think that the truth can only be found through my } \\
\text { religious or worldview orientation }\end{array}$ & 1.79 & 1.44 & .83 & - \\
\hline & $\begin{array}{l}\text { I am convinced that only my religious or worldview } \\
\text { orientation is the right one }\end{array}$ & 1.94 & 1.47 & .67 & - \\
\hline & $\begin{array}{l}\text { I would like to live in a society in which everyone has } \\
\text { the same life orientation as I have }\end{array}$ & 2.44 & 1.65 & .51 & - \\
\hline & Subscale total & 2.06 & 1.23 & & \\
\hline \multirow[t]{4}{*}{$\begin{array}{l}\text { Inclusivism } \\
\alpha=.52\end{array}$} & $\begin{array}{l}\text { I like to connect with people who have a different } \\
\text { religious or worldview orientation than my own }\end{array}$ & 3.77 & 1.47 & - & .62 \\
\hline & $\begin{array}{l}\text { It is no problem for me if my country is or will be } \\
\text { governed by people with a different religious or } \\
\text { worldview orientation than my own }\end{array}$ & 3.16 & 1.73 & - & .50 \\
\hline & $\begin{array}{l}\text { People with a different religious or worldview } \\
\text { orientation than I have are probably just as moral as } \\
\text { those with the same religious or worldview } \\
\text { orientation }\end{array}$ & 4.14 & 1.37 & - & .44 \\
\hline & Subscale total & 3.71 & 1.12 & & \\
\hline $\begin{array}{l}\text { Variance } \\
\text { explained } \\
\text { (\%) }\end{array}$ & & & & 33.54 & 24.09 \\
\hline
\end{tabular}

Note. Correlation between factors: -.17

${ }^{1}$ Ranging from 1 to $5(1=$ totally disagree; $5=$ totally agree $)$ 
Table 14 Chaplain's professional profile: factor loadings $(>.35)$ for principal axis factoring with oblimin rotation $(n=44)$

\begin{tabular}{|c|c|c|c|c|c|}
\hline Variable & Item $^{1}$ & $\mathrm{M}^{2}$ & $\mathrm{SD}$ & $\begin{array}{l}\text { Factor } \\
\text { loading } \\
\text { factor } 1\end{array}$ & $\begin{array}{l}\text { Factor } \\
\text { loading } \\
\text { factor } 2\end{array}$ \\
\hline $\begin{array}{l}\text { Ability to provide } \\
\text { interfaith } \\
\text { spiritual care }\end{array}$ & $\begin{array}{l}\text { I am very capable of connecting with people who } \\
\text { clearly have another religious or worldview } \\
\text { orientation }\end{array}$ & 4.25 & .75 & .89 & - \\
\hline \multirow[t]{4}{*}{$\alpha=.86$} & $\begin{array}{l}\text { I am very capable of empathizing with the religious } \\
\text { or worldview orientation of my client }\end{array}$ & 4.04 & .74 & .89 & - \\
\hline & $\begin{array}{l}\text { I have sufficient knowledge of other religious or } \\
\text { worldview orientations }\end{array}$ & 3.60 & .78 & .73 & - \\
\hline & $\begin{array}{l}\text { I am sufficiently skilled in dealing with people who } \\
\text { clearly have a different religious or worldview } \\
\text { orientation }\end{array}$ & 3.93 & .84 & .64 & - \\
\hline & Subscale total & 3.95 & .65 & & \\
\hline $\begin{array}{l}\text { Perspective on } \\
\text { interfaith } \\
\text { spiritual care }\end{array}$ & $\begin{array}{l}\text { I think my main goal is to provide spiritual care for } \\
\text { clients with the same religious or worldview } \\
\text { orientation }(\mathrm{P})^{3}\end{array}$ & 1.40 & .86 & - & .76 \\
\hline \multirow[t]{5}{*}{$\alpha=.73$} & $\begin{array}{l}\text { I would only want to practice rituals with people } \\
\text { who have the same religious or worldview } \\
\text { orientation as I have }(\mathrm{P})\end{array}$ & 2.13 & 1.14 & - & .64 \\
\hline & $\begin{array}{l}\text { I prefer to have in-depth and meaningful } \\
\text { conversations with people who have the same } \\
\text { religious or worldview orientation as I have }(\mathrm{P})\end{array}$ & 1.58 & .94 & $-.42^{4}$ & .47 \\
\hline & $\begin{array}{l}\text { I think my main goal is to provide spiritual care to } \\
\text { everyone, irrespective of someone's religious or } \\
\text { worldview orientation }(U)\end{array}$ & 4.64 & .71 & $.46^{4}$ & -.35 \\
\hline & $\begin{array}{l}\text { I see possibilities to practice rituals that cross borders } \\
\text { of religious or worldview orientations (U) }\end{array}$ & 4.02 & 1.01 & - & -.45 \\
\hline & Subscale total 5 & 4.31 & .66 & & \\
\hline $\begin{array}{l}\text { Variance explained } \\
\text { (\%) }\end{array}$ & & & & 45.32 & 17.51 \\
\hline
\end{tabular}

Note. Correlation between factors: -.36

${ }^{1}$ The following items were deleted from analysis due to insufficient loading on the intended subscale $(<.35)$ : "I have an open attitude towards people who clearly have a different religious or worldview orientation," "I am eager to share my religious or worldview orientation in conversations with people who have a different religious or worldview orientation," and "I think that for conversations it makes no difference whether the chaplain and the client belong to the same or a different religious or worldview orientation."

${ }^{2}$ Ranging from 1 to 5 ( 1 = totally disagree; 5 = totally agree)

${ }^{3} \mathrm{P}$ refers to items that reflect the "particularist" stance on the continuum, and U refers to items reflecting the "universalist" stance on the continuum

${ }^{4}$ This item loaded on two scales simultaneously and remained in the analysis as part of the subscale it was theoretically intended to belong to (factor 2)

${ }^{5}$ For the overall subscale score, $\mathrm{P}$ items have been reversed to reflect the continuum from a more particularistic to a more universalistic perspective (the higher the score, the more universalistic)

Acknowledgements The authors would like to thank Jolanda te Paske for her assistance in data collection, and prof. dr. R. Ruard Ganzevoort and dr. Erik Olsman for their valuable advice on earlier versions of this manuscript.

Data availability statement For details on the questionnaire and data set used and analyses conducted in this study, please contact the first author. 
Author contribution Both authors contributed to the study conception and design. Data collection was performed by Liefbroer. Material preparation and data analysis were performed by Liefbroer with guidance of Nagel. The first draft of the manuscript was written by Liefbroer and Nagel commented on previous versions of the manuscript. Both authors read and approved the final manuscript.

\section{Declarations}

Conflict of interest The authors declare that they have no conflict of interest.

Open Access This article is licensed under a Creative Commons Attribution 4.0 International License, which permits use, sharing, adaptation, distribution and reproduction in any medium or format, as long as you give appropriate credit to the original author(s) and the source, provide a link to the Creative Commons licence, and indicate if changes were made. The images or other third party material in this article are included in the article's Creative Commons licence, unless indicated otherwise in a credit line to the material. If material is not included in the article's Creative Commons licence and your intended use is not permitted by statutory regulation or exceeds the permitted use, you will need to obtain permission directly from the copyright holder. To view a copy of this licence, visit http://creativecommons.org/licenses/by/4.0/.

\section{References}

Abu-Ras, W., \& Laird, L. (2011). How Muslim and non-Muslim chaplains serve Muslim patients? Does the interfaith chaplaincy model have room for Muslims' experiences? Journal of Religion and Health, 50(1), 46-61. https://doi.org/10.1007/s10943-010-9357-4.

Allport, G. W. (1954). The nature of prejudice. Cambridge: Perseus Books.

Allport, G. W., \& Ross, J. M. (1967). Personal religious orientation and prejudice. Journal of Personality and Social Psychology, 5(4), 432-443. https://doi.org/10.1037/0022-3514.5.4.432.

Ammerman, N. T. (2013). Spiritual but not religious? Beyond binary choices in the study of religion. Journal for the Scientific Study of Religion, 52(2), 258-278. https://doi.org/10.1111/jssr.12024.

Anderson, R. G. (2004). The search for spiritual/cultural competency in chaplaincy practice: Five steps that mark the path. Journal of Health Care Chaplaincy, 13(2), 1-24. https://doi.org/10.1300/J080v13n02_01.

Becci, I., \& Roy, O. (2015). Religious diversity in European prisons: Challenges and implications for rehabilitation. Cham, Switzerland: Springer.

Bender, C., Cadge, W., Levitt, P., \& Smilde, D. (2013). Religion on the edge: De-centering and re-centering the sociology of religion. New York: Oxford University Press.

Berghuijs, J. (2017). Multiple religious belonging in the Netherlands: An empirical approach to hybrid religiosity. Open Theology, 3(1), 19-37. https://doi.org/10.1515/opth-2017-0003.

Berghuijs, J., \& Liefbroer, A. I. (2017). Religieuze en levensbeschouwelijke diversiteit in het leven en werk van geestelijk verzorgers: Onderzoeksrapport [Religious and worldview diversity in the life and work of spiritual caregivers: Research report.] https://vgvz.nl/wp-content/uploads/2017/11/Rapportage-GV-enquêtedefinitief-herzien.pdf. Accessed 3 December 2019.

Bidwell, D. R., \& Marshall, J. L. (2006). Formation: Content, context, models and practices. American Journal of Pastoral Counseling, 8(3-4), 1-7. https://doi.org/10.1300/J062v08n03 01.

Broer, N. A., De Muynck, B., Potgieter, F. J., Wolhuter, C. C., \& Van der Walt, J. L. (2014). Measuring religious tolerance among final year education students: The birth of a questionnaire. International Journal for Religious Freedom, 7(1/2), 77-96.

Brown, R. K., \& Brown, R. E. (2011). The challenge of religious pluralism: The association between interfaith contact and religious pluralism. Review of Religious Research, 53(3), 323-340. https://doi.org/10.1007/ s13644-011-0014-5.

Bruinsma-de Beer, J. (2006). Pastor in perspectief. In Een praktisch-theologisch onderzoek naar de competentie van de pastor [Pastor in perspective: A practical-theological investigation into the competence of the pastor]. Gorichem: Narratio.

Byrne, D. (1971). The attraction paradigm. New York: Academic Press.

Cadge, W. (2012). Paging god: Religion in the halls of medicine. Chicago: University of Chicago Press.

Cadge, W., \& Konieczny, M. E. (2014). "Hidden in plain sight": The significance of religion and spirituality in secular organizations. Sociology of Religion, 75(4), 551-563. https://doi.org/10.1093/socrel/sru043. 
Cadge, W., \& Sigalow, E. (2013). Negotiating religious differences: The strategies of interfaith chaplains in healthcare. Journal for the Scientific Study of Religion, 52(1), 146-158. https://doi.org/10.1111/jssr.12008.

CBS (2018). Religieuze betrokkenheid [Religious affiliation]. https://statline.cbs.nl/Statweb/publication/?DM= SLNL\&PA=82904ned \&D1=0-7\&D2=0\&D3=a\&VW=T. Accessed 28 November 2019.

CBS (2019). Bevolking; hoogstbehaald onderwijsniveau en onderwijsrichting [Population; highest level of education and educational direction]. https:/opendata.cbs.nl/statline/\#/CBS/nl/dataset/82816NED/table?ts= 1568802082996. Accessed 18 September 2019.

Chinitz, J. G., \& Brown, R. A. (2001). Religious homogamy, marital conflict, and stability in same-faith and interfaith Jewish marriages. Journal for the Scientific Study of Religion, 40(4), 723-733. https://doi.org/10. 1111/0021-8294.00087.

Christensen, H. R., Høeg, I. M., Kühle, L., \& Nordin, M. (2019). Rooms of silence at three universities in Scandinavia. Sociology of Religion, 80(3), 299-322. https://oi.org/10.1093/socrel/sry040.

De Groot, C. N. (2018). The liquidation of the church. Abingdon, England: Routledge.

Duriez, B., Soenens, B., \& Hutsebaut, D. (2005). Introducing the shortened Post-critical belief scale. Personality and Individual Differences, 38(4), 851-857. https://doi.org/10.1016/j.paid.2004.06.009.

Eisinga, R., Need, A., Coenders, M., De Graaf, N. D., Lubbers, M., \& Scheepers, P., with assistance of Levels, M., \& Thijs, P. (2005). Religion in Dutch society: Documentation of a national survey on religious and secular attitudes and behaviour in 2005. Amsterdam, The Netherlands: DANS/Pallas PublicationsAmsterdam University Press.

Ellis, M. R., \& Campbell, J. D. (2005). Concordant spiritual orientations as a factor in physician-patient spiritual discussions: A qualitative study. Journal of Religion and Health, 44(1), 39-53. https://doi.org/10.1007/ s10943-004-1144-7.

Fawcett, T. N., \& Noble, A. (2004). The challenge of spiritual care in a multi-faith society experienced as a Christian nurse. Journal of Clinical Nursing, 13(2), 136-142. https://doi.org/10.1046/j.1365-2702.2003. 00870.x.

Flohr, A. (2009). Competences for pastoral work in multicultural and multifaith societies. In D. S. Schipani \& L. D. Bueckert (Eds.), Interfaith spiritual care: Understandings and practices (pp. 143-169). Kitchener, ON: Pandora Press.

Fontaine, J. R. J., Duriez, B., Luyten, P., \& Hutsebaut, D. (2003). The internal structure of the Post-Critical Belief Scale. Personality and Individual Differences, 35(3), 501-518. https://doi.org/10.1016/S0191-8869(02) 00213-1.

Galek, K., Silton, N. R., Vanderwerker, L. C., Handzo, G. F., Porter, M., Montonye, M. G., \& Fleenor, D. W. (2010). To pray or not to pray: Considering gender and religious concordance in praying with the ill. Journal of Health Care Chaplaincy, 16(1-2), 42-52. https://doi.org/10.1080/08854720903529694.

Ganzevoort, R. R., Ajouaou, M., Van der Braak, A., De Jongh, E., \& Minnema, L. (2014). Teaching spiritual care in an interfaith context. Journal for the Academic Study of Religion, 27(2), 178-197. https://doi.org/10. 1558/jasr.v27i2.178.

Ganzevoort, R. R., \& Visser, J. (2007). Zorg voor het verhaal. Achtergrond, methode en inhoud van pastorale begeleiding [to care for the story: Background, method and content of pastoral counseling]. Zoetermeer, The Netherlands: Meinema.

Glock, C. Y., \& Stark, R. (1965). Religion and society in tension. Chicago: Rand McNally.

Heitink, G. (2001). Biografie van de dominee [Biography of the pastor]. Baarn, The Netherlands: Ten Have.

Hodge, D. R. (2018). Spiritual competence: What it is, why it is necessary, and how to develop it. Journal of Ethnic \& Cultural Diversity in Social Work, 27(2), 124-139. https://oi.org/10.1080/15313204.2016. 1228093.

Hodge, D. R., \& Lietz, C. A. (2014). Using spiritually modified cognitive-behavioral therapy in substance dependence treatment: Therapists' and clients' perceptions of the presumed benefits and limitations. Health and Social Work, 39(4), 200-210.

Idler, E. L., Grant, G. H., Quest, T., Binney, Z., \& Perkins, M. M. (2015). Practical matters and ultimate concerns, "doing," and "being": A diary study of the chaplain's role in the care of the seriously ill in an urban acute care hospital. Journal for the Scientific Study of Religion, 54(4), 722-738. https://doi.org/10.1111/jssr. 12235.

Inglehart, R., C. Haerpfer, A. Moreno, C. Welzel, K. Kizilova, J. Diez-Medrano, M. Lagos, P. Norris, E. Ponarin \& B. Puranen et al. (eds.). 2014. World values survey: Round six - country-pooled Datafile version: www. worldvaluessurvey.org/WVSDocumentationWV6.jsp. Madrid: JD Systems Institute.

Kellems, I. S., Hill, C. E., Crook-Lyon, R. E., \& Freitas, G. (2010). Working with clients who have religious/ spiritual issues: A survey of university counseling center therapists. Journal of College Student Psychotherapy, 24(2), 139-155. https://doi.org/10.1080/87568220903558745.

Koenig, H. G., \& Büssing, A. (2010). The Duke University religion index (DUREL): A five-item measure for use in epidemological studies. Religions, 1(1), 78-85. https://doi.org/10.3390/rel1010078. 
Lang, G., \& Van der Molen, H. T. (2012). Psychologische gespreksvoering. Een basis voor hulpverlening [Psychological conversation techniques: A guide for caregiving]. Amsterdam: Boom.

Lartey, E. Y. (2003). In living color: An intercultural approach to pastoral care and counseling (2nd ed.). London: Jessica Kingsley.

Liefbroer, A. I., \& Berghuijs, J. (2017). Religieuze en levensbeschouwelijke diversiteit in het werk van geestelijk verzorgers [Religious and worldview diversity in the work of spiritual caregivers]. Tijdschrift Geestelijke Verzorging, 20(3), 24-33.

Liefbroer, A. I., \& Berghuijs, J. (2019). Spiritual care for everyone? An analysis of personal and organizational differences in perceptions of religious diversity among spiritual caregivers. Journal of Health Care Chaplaincy, 25(3), 110-129. https://doi.org/10.1080/08854726.2018.1556549.

Liefbroer, A. I., Ganzevoort, R. R., \& Olsman, E. (2019). Addressing the spiritual domain in a plural society: What is the best mode of integrating spiritual care into healthcare? Mental Health Religion \& Culture, 22(3), 244-260. https://doi.org/10.1080/13674676.2019.1590806.

Liefbroer, A. I., Olsman, E., Ganzevoort, R. R., \& Van Etten-Jamaludin, F. S. (2017). Interfaith spiritual care: A systematic review. Journal of Religion and Health, 56(5), 1776-1793. https://doi.org/10.1007/s10943-0170369-1.

Liefbroer, A. I., Van der Braak, A. F. M., \& Kalsky, M. (2018). Multiple religious belonging among visitors of Dominican spiritual centers in the Netherlands. Journal of Contemporary Religion, 33(3), 407-426. https:// doi.org/10.1080/13537903.2018.1535362.

Liu, L. A., Chua, C. H., \& Stahl, G. K. (2010). Quality of communication experience: Definition, measurement, and implications for intercultural negotiations. Journal of Applied Psychology, 95(3), 469-487. https://oi. org/10.1037/a0019094.

Marin, D. B., Sharma, V., Sosunov, E., Egorova, N., Goldstein, R., \& Handzo, G. F. (2015). Relationship between chaplain visits and patient satisfaction. Journal of Health Care Chaplaincy, 21(1), 14-24. https:// doi.org/10.1080/08854726.2014.981417.

Mayers, C., Leavey, G., Vallianatou, C., \& Barker, C. (2007). How clients with religious or spiritual beliefs experience psychological help-seeking and therapy: A qualitative study. Clinical Psychology and Psychotherapy, 14(4), 317-327. https://doi.org/10.1002/cpp.542.

Merino, S. M. (2010). Religious diversity in a "Christian nation": The effects of theological exclusivity and interreligious contact on the acceptance of religious diversity. Journal for the Scientific Study of Religion, 49(2), 231-246. https://doi.org/10.1111/j.1468-5906.2010.01506.x.

Myers, S. M. (2006). Religious homogamy and marital quality: Historical and generational patterns, 1980-1997. Journal of Marriage and Family, 68(2), 292-304. https://doi.org/10.1111/j.1741-3737.2006.00253.x.

Ouwehand, E., Braam, A. W., Renes, J. W., Muthert, H. J. K., \& Zock, H. T. (2020). Holy apparition or hyperreligiosity: Prevalence of explanatory models for religious and spiritual experiences in patients with bipolar disorder and their associations with religiousness. Pastoral Psychology, 69, 29-45. https://doi.org/10.1007/ s11089-019-00892-3.

Pesut, B., \& Reimer-Kirkham, S. (2010). Situated clinical encounters in the negotiation of religious and spiritual plurality: A critical ethnography. International Journal of Nursing Studies, 47(7), 815-825. https://doi.org/ 10.1016/j.ijnurstu.2009.11.014.

Petts, R. J., \& Knoester, C. (2007). Parents' religious heterogamy and children's well-being. Journal for the Scientific Study of Religion, 46(3), 373-389. https://doi.org/10.1111/j.1468-5906.2007.00364.x.

Post, L., \& Liefbroer, A. I. (2019). Reducing distress in cancer patients-A preliminary evaluation of short-term coaching by expert volunteers. Psycho-Oncology, 28(8), 1762-1766. https://doi.org/10.1002/pon.5111.

Saroglou, V. (2011). Believing, bonding, behaving, and belonging: The big four religious dimensions and cultural variation. Journal of Cross-Cultural Psychology, 42(8), 1320-1340. https://doi.org/10.1177/ 0022022111412267.

Shen, M. J., Peterson, E. B., Costas-Muniz, R., Hernandez, M. H., Jewell, S. T., Matsoukas, K., \& Bylund, C. L. (2018). The effects of race and racial concordance on patient-physician communication: A systematic review of the literature. Journal of Racial and Ethnic Health Disparities, 5, 117-140. https://doi.org/10.1007/ s40615-017-0350-4.

Smart, N. (1998). Dimensions of the sacred: An anatomy of the world's beliefs. Berkeley: University of California Press.

Stifoss-Hanssen, H., Danbolt, L. J., \& Frøkedal, H. (2019). Chaplaincy in northern Europe. An overview from Norway. Tidsskrift for Praktisk Teologi: Nordic Journal of Practical Theology, 36(2), 60-70.

Swift, C. (2013). A state health service and funded religious care. Health Care Analysis, 21(3), 248-258. https:// doi.org/10.1007/s10728-013-0252-5.

Tajfel, H., \& Turner, J. C. (1986). The social identity of intergroup behavior. In S. Worchel \& W. G. Austin (Eds.), Psychology of intergroup relations (pp. 7-24). Chicago: Nelson-Hall.

Taylor, C. (2007). A secular age. Cambridge, MA: Belknap Press of Harvard University Press. 
Van Nieuw Amerongen-Meeuse, J. C., Schaap-Jonker, H., Schuhmann, C., Anbeek, C., \& Braam, A. W. (2018). The "religiosity gap" in a clinical setting: Experiences of mental health care consumers and professionals. Mental Health, Religion \& Culture, 21(7), 737-752. https://doi.org/10.1080/13674676.2018.1553029.

Van Oudenhoven, J. P., Judd, C. M., \& Hewstone, M. (2000). Additive and interactive models of crossed categorization in correlated social categories. Group Processes and Intergroup Relations, 3(3), $285-295$. https://doi.org/10.1177/1368430200033004.

Woodhead, L. (2016). Intensified religious pluralism and de-differentiation: The British example. Society, 53, 41-46. https://doi.org/10.1007/s12115-015-9984-1.

Wulff, D. M. (1997). Psychology of religion: Classic and contemporary views. New York: Wiley.

Zock, H. (2019). Chaplaincy in the Netherlands. The search for a professional and a religious identity. Tidsskrift for Praktisk Teologi. Nordic Journal of Practical Theology (2), 11-21.

Publisher's Note Springer Nature remains neutral with regard to jurisdictional claims in published maps and institutional affiliations. 